\title{
ESTIMATION OF STATURE FROM DIMENSIONS OF HAND AND FOOT IN EGYPTIAN POPULATION AT GREATER CAIRO
}

\author{
Sherein S. Ghaleb, Mohamed Adly, Dalia Abd-Elwahab Hassan*, Magdi Fouad ** \\ Department of Forensic Medicine and Clinical Toxicology, \\ Faculty of Medicine, Cairo University, \\ Department of Forensic Medicine and Clinical Toxicology, \\ Faculty of Medicine, Beni-Suif University*, \\ Department of Anatomy, Faculty of Medicine, Cairo University**
}

\begin{abstract}
In the study of human remains, forensic anthropologists must have the necessary knowledge of human variation specific to a given region and population in order to be able to identify any unknown individual. Height estimation by measurement of various long bones has been attempted by several workers with variable degree of success. Population based differences exist in both metric and morphological features of the skeleton and these have changed over time. Therefore, it is vital for biological anthropologists to conduct up-to-date research on diverse population groups residing in different geographic zones. Objective: to establish a relationship between the stature and both foot $\&$ hands dimensions among male and female individuals of Greater Cairo. Subjects and methods: Measurements of stature, foot length, foot width, hand length, and hand width were recorded from 500 adult males and from 500 adult females (age range 18-60 years). Results: the present study has established definite correlation between stature and foot-length and also regression equations have been established. Conclusion: the established correlation in the present study will help in establishing identity of individuals in greater Cairo.
\end{abstract}

Keywords: Stature; Dimensions of Hand; Dimensions of Foot; Egyptian Population.

\section{INTRODUCTION}

Fields of anthropology include cultural anthropology, archeology, and physical anthropology. Forensic anthropology is subfield of physical anthropology (Albert, 2012). Anthropometry is a common non invasive inexpensive method used to assess the proportions size of human 
body. It is a reflection of health and nutrition (WHO, 1986).

Anthropometry has been widely used in the recent years and the interpretation of the results became very important to be correct and well understood. The choice of anthropometric measures and their application and interpretation differ between the situations where they are applied (Beaton, 1990).

Many countries due to ethnic diversity have developed anthropometric database for different population groups such as civilian, students and military personnel (Bolstad et al., 2001). The bodily proportion refers to a scale calculated as a ratio between a body dimension and another dimension used as a reference. Stature is considered as the most common reference dimension (Pheasant, 1996; and Lin et al., 2004).

Stature is considered to be one of the most important indicators of body size and it results from multi-factorial biological process. It is determined by hereditary factors that are affected by environmental conditions such as nutrition and climate (Canda, 2009; and Krishan et al., 2011). Estimation of the stature is affected by several factors such as the age, sex, and socioeconomic level (Fogel,
1994; WHO, 1995; and De Onis \&. Habicht, 1996).

In forensic examinations, several studies have demonstrated that the stature of the assailant can estimated from hand imprints and footprints at the crime scene. Likehood, the stature of a victim can be estimated when a part of body is all that remains such as a long bone (Ozaslan et al., 2003; and Ilayperuma et al., 2009).

The dimensions of the foot have been used for the determination of sex, age, and stature of an individual (Kanchan et al., 2008). Forensic podiatry is to attribute an individual with a scene of crime and to establish personal identity in forensic examination (DiMaggio \& Vernon, 2011).

The relation between the stature and foot dimension has been investigated and significant correlation was found between the stature and foot length in males on one side and stature and foot width in females on the other side (Kanchan et al, 2008). On the other hand, several studies stated that the hand lengths can be used as an alternative measure to stature (Lacia et al., 2002; and Waghmare et al., 2011).

\section{AIM OF THE WORK}

The current study is directed to establish a relationship between the 
stature on one side and foot $\&$ hands dimensions among male and female individuals of Greater Cairo on the other side.

\section{SUBJECTS \& METHODS}

Measurements of stature, foot length, foot width, hand length, and hand width were recorded from 500 adult males and from 500 adult females (age range 18-60 years). Measurements (in millimeters) were taken using standardized anthropometric measuring equipment; sliding, spreading calipers and standard measuring tape (figure $1 \& 2)$.

The majority of the examined cases (about 70\%) were students at Faculty of Medicine, Cairo University. The remainders are neighbors and relatives of the examiner. Ethically, an informed consent was taken from the subjects of the study. None of the participants was coerced or rewarded. The protocol of the present study has been accepted by the research ethical committee.

The inclusion criteria included both healthy males and females aged between 18 and 60 years with known age and sex. The exclusion criteria included any individual with congenital, pathological or traumatic bone deformities.
Total height is measured from the top of the head to the soles of the bare feet using the stadiometer with the person in Frankfort horizontal plane (fig 2a). The headboard is lowered till the top of the head and the height was then recorded in centimeter. Alternatively, if the stadiometer is unavailable, a tapemeasure can be used (fig.2b).

With the help of sliding Calipers, foot length was taken between the most projecting points posteriorly (Pternion) and anteriorly (Acropodion) of the first or second toe whichever was bigger (fig3).

The foot width (broadest) point of the foot is measured between the medial prominence of the first metatarso-phalangeal (MTP) joint and the lateral prominence of the fifth MTP joint of the foot. It is measured on sole of the foot using the tapemeasure, calipers, or clear ruler. Patients is in a relaxed position, sitting, or lying down; however, foot width may be most easily measured with the individual standing on the tape-measure (fig4). A line is drawn on the foot marking the MTP joints and the measure was taken between the markings. Alternatively, using the sliding Calipers, foot breadth was measured from metatarsale-tibiale to the metatarsale-fibulare point. 
The length of the hand is measured from the tip of the middle finger to the distal crease at the wrist to by tape-measure, calipers, or clear ruler. The wrist is held in neutral position, and the fingers are fully extended (fig5). A line was drawn on the hand and the measure was taken from the estimated points. In cases where the subjects have multiple wrist creases, choose the most distal crease. Alternatively, it can be measured using a measuring tape from mid-point below radial and ulnar tuberosities to the tip of middle finger.

Hand width is measured from base of 5th to 2 nd metacarpus using a sliding caliper. Alternatively, the width of the palm of the hand is measured from the edge of the hand on one side to the edge of the hand on the other side at the level of the metacarpo-phalangeal joints by tapemeasure, calipers, or clear ruler. The wrist is in a neutral position with the fingers fully extended. A line was drawn on the hand and the measure was taken from the estimated points (fig6).

\section{STATISTICAL ANALYSIS}

The measurements obtained were statistically analyzed using SPSS 14.0. Analysis of the stature, hand length, hand width, foot length, foot width, age and stature between male and female individuals was done by paired t-test. Karl Pearson's correlation coefficients and linear regression analysis were done.
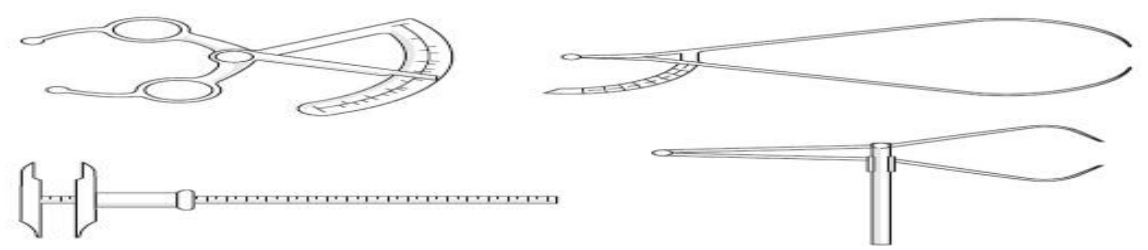

Figure (1): Anthropometric instruments 

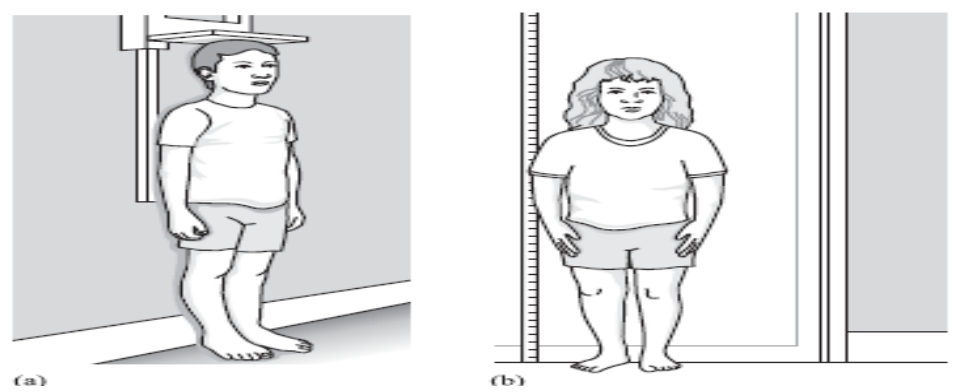

Figure (2): Measuring standard height with a stadiometer (a) or a tape-measure (b) (Hall et al., 2007).

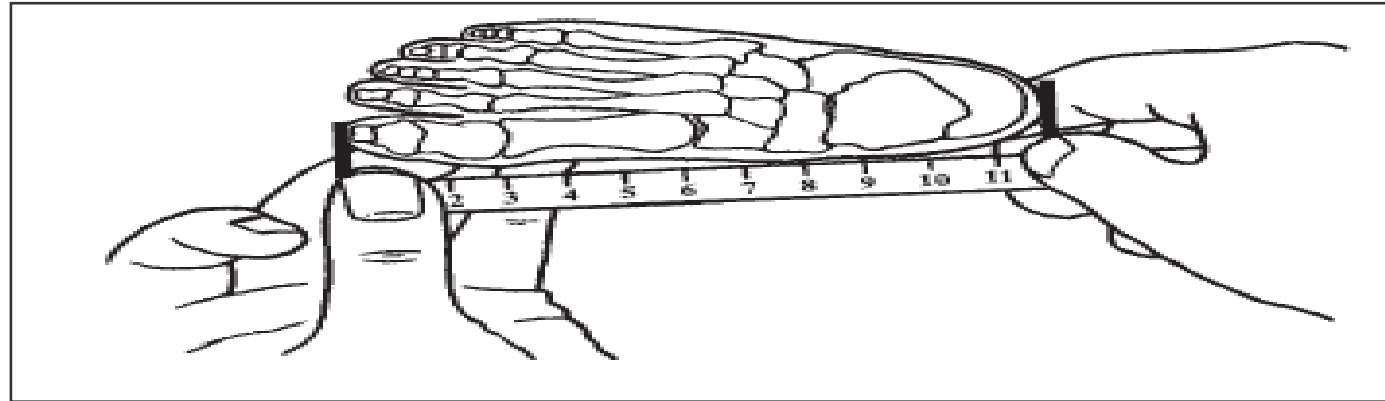

Figure (3): Measuring foot length (Hall et al., 2007).

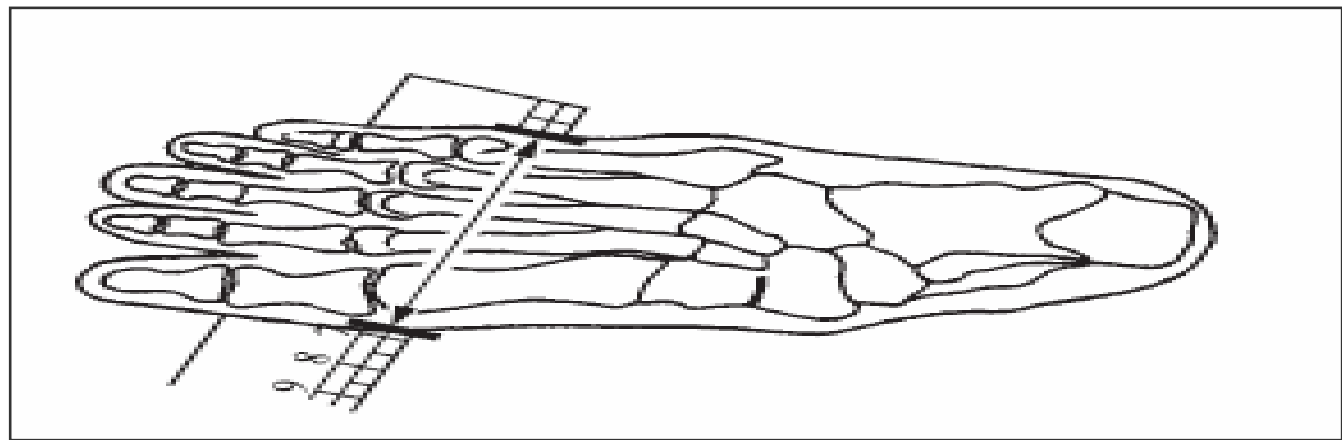

Figure (4): Measuring foot width (Hall et al., 2007).

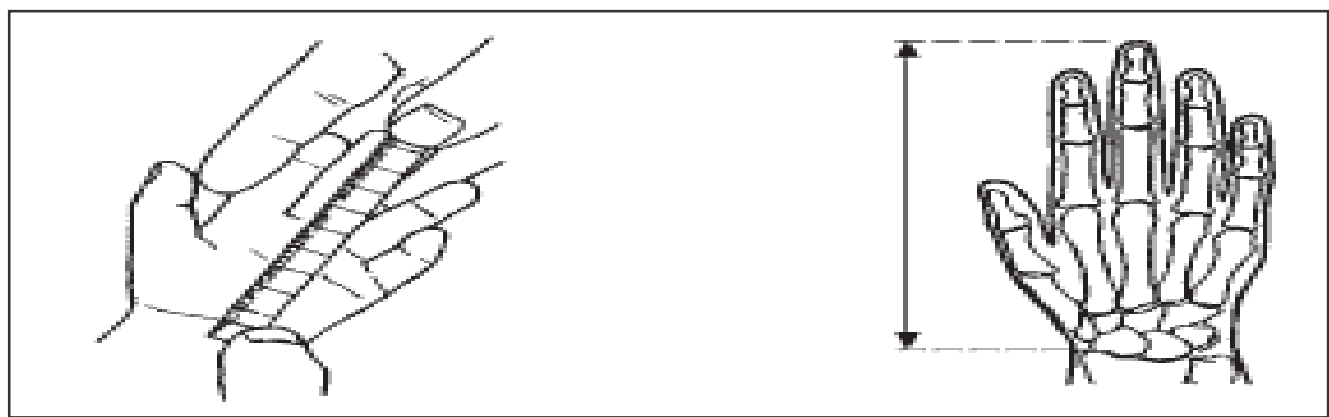

Figure (5): Measuring hand length (Hall et al., 2007). 


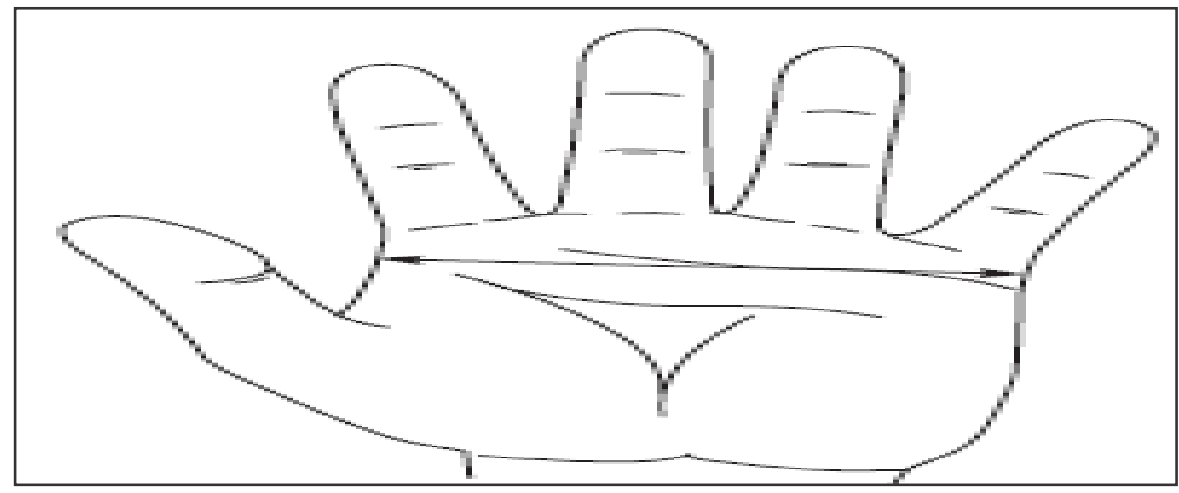

Figure (6): Measuring palm width (Hall et al., 2007).

\section{RESULTS}

In the current study, the mean age of the two studied groups was in men $(27.98 \pm 10.0)$ and in women $(33.46 \pm 10.4)$ respectively. All the measurements were significantly higher in males than in females. The measurements two studied groups are as shown in table (1), fig (7) and fig (8).

The frequency distribution of toe number used in foot length measurement in men was $92.2 \%$ for $1^{\text {st }}$ toe and $7.8 \%$ for $2^{\text {nd }}$ toe. As for women, it was $81 \%$ for the $1^{\text {st }}$ toe and $19 \%$ for the $2^{\text {nd }}$ toe as shown in fig (9).

Linear regression analysis was done to estimate the contribution of each of the following parameters (hand length, hand width, foot length and foot width) to the stature. The linear regression equations are as follows:

$$
\text { Stature }=67.977+5.11 \text { (Hand length) }
$$$$
\text { Stature }=126.244+4.417 \text { (Hand }
$$
width)

$$
\text { Stature }=114.748+1.983(\text { Foot }
$$
length)
Stature $=136.184+2.799($ Foot width)

The estimated regression equations accounted for $40.8 \%, 10.1 \%, 13.6 \%$ and $10.1 \%$ of the variability in stature, respectively, with a $\mathrm{P}$ value $<0.001$ for all.

A significant positive correlation was observed between the calculated stature and the actual measured stature by Spearman's correlation analysis according to the four parameters $(\mathrm{r}=$ $0.674, \quad 0.311, \quad 0.379$ and 0.296 respectively with a $\mathrm{P}$ value $<0.001$ for all).

To assess the effective factors for stature, a multivariate stepwise linear regression analysis was conducted with respect to age, gender, hand length, hand width, foot length, foot width and toe number. Analysis revealed that sex $(\mathrm{P}$ $<0.001)$, Hand length $(\mathrm{P}<0.001)$, age $(\mathrm{P}<0.001)$, foot length $(\mathrm{P}<0.001)$, hand width $(\mathrm{P}=0.001)$ and foot width $(\mathrm{P}=$ 0.013) had independent and significant contribution to the overall variability in stature. The multivariate linear regression equation of stature is as follows: 
Stature $=100.220+9.578 \times$ (gender) +2.422 (hand length) $-0.098 \times$ (age) + 0.509 (foot length) +1.123 (hand width) -0.539 (foot width)

Gender is coded as 1 for males and 0 for females while all other variables are in $\mathrm{cm}$. So the equation for males was as follows:

Stature $=100.220+9.578 \times(1)+$ 2.422 (hand length) $-0.098 \times$ (age) + 0.509 (foot length) +1.123 (hand width) -0.539 (foot width)

On the other hand, the equation for females was as follows:

Stature $=100.220+9.578 \times(0)+$ 2.422 (hand length) $-0.098 \times$ (age) + 0.509 (foot length) +1.123 (hand width) -0.539 (foot width)

The estimated regression equation was able to account for $64 \%\left[\mathrm{R}^{2}\left(\mathrm{R}_{\text {adj }}^{2}\right)=\right.$
$0.642(0.64)]$ of the overall variability in stature.

A significant positive correlation was observed between the calculated stature and the actual measured stature by Spearman's correlation analysis $(\mathrm{r}=0.81$,

$\mathrm{P}<0.001)$. According to the above equation, it can be seen that the stature increase, on average, by $9.578 \mathrm{~cm}$ for male gender holding all other variables constant. It increases also by $2.422 \mathrm{~cm}, 0.509 \mathrm{~cm}$ and $1.123 \mathrm{~cm}$ for every one $\mathrm{cm}$ increase in hand length, foot length and hand width, respectively, holding all other variables constant. On the other hand, holding other variables constant, the stature decreases, on average, by $0.098 \mathrm{~cm}$ and $0.539 \mathrm{~cm}$ for every one year increase in age and one $\mathrm{cm}$ increase in foot width, respectively.

Table (1): Mean values \pm SD of the age and different measurements in the two studied groups.

\begin{tabular}{|l|c|c|c|}
\hline & Male $(\mathrm{n}=500)$ & Female $(\mathrm{n}=500)$ & $\mathrm{P}$ \\
\hline \multicolumn{1}{|c|}{ Age } & $27.98 \pm 10.0$ & $33.46 \pm 10.4$ & $<0.001$ \\
\hline Stature $(\mathrm{cm})$ & $172.71 \pm 6.5$ & $159.2 \pm 6.08$ & $<0.001$ \\
\hline Hand length $(\mathrm{cm})$ & $19.79 \pm 1.00$ & $18.55 \pm 0.94$ & $<0.001$ \\
\hline Hand width $(\mathrm{cm})$ & $9.15 \pm 0.67$ & $8.82 \pm 0.62$ & $<0.001$ \\
\hline Foot length $(\mathrm{cm})$ & $26.52 \pm 1.80$ & $25.39 \pm 1.52$ & $<0.001$ \\
\hline Foot width $(\mathrm{cm})$ & $10.99 \pm 1.14$ & $10.27 \pm 0.80$ & $<0.001$ \\
\hline
\end{tabular}

$\mathrm{P}<0.01=$ significant 


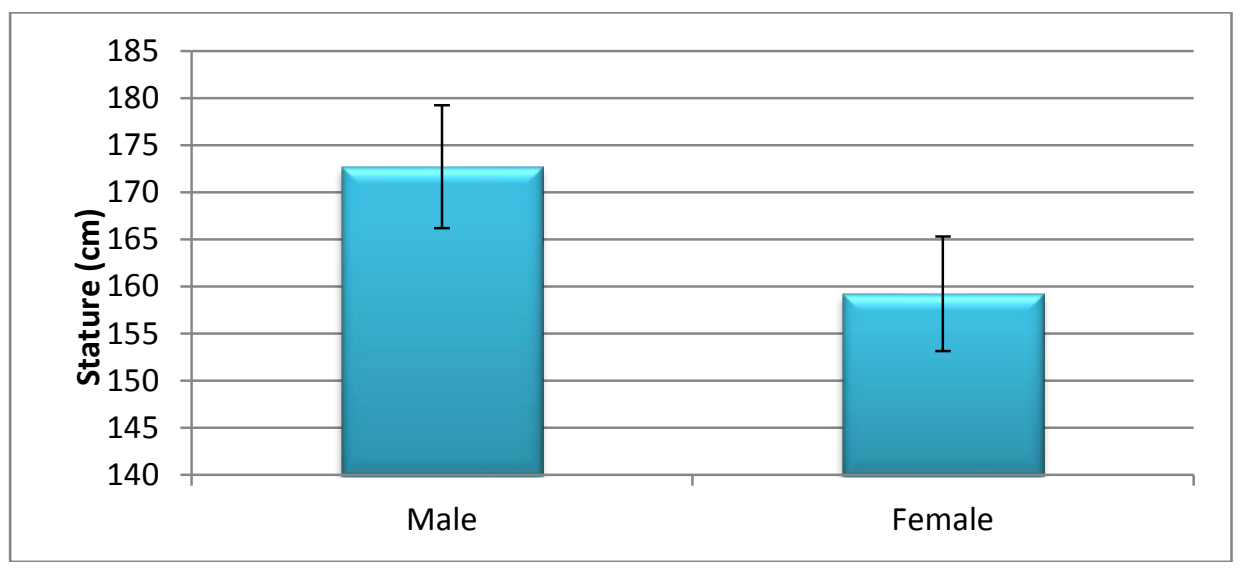

Figure (7): Mean Stature of the two studied groups.

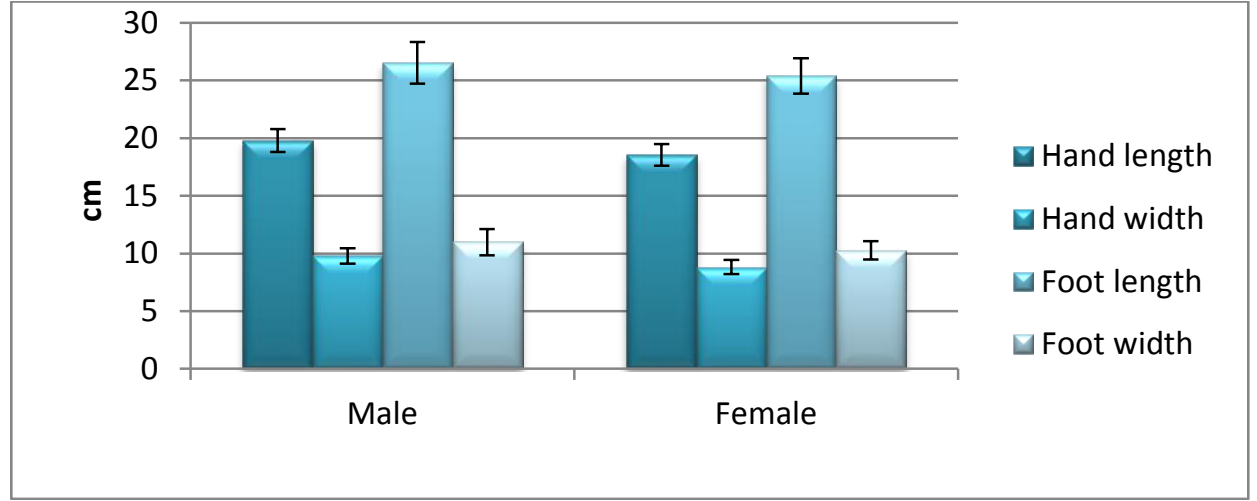

Figure (8): Mean values of different measurements of the two studied groups.

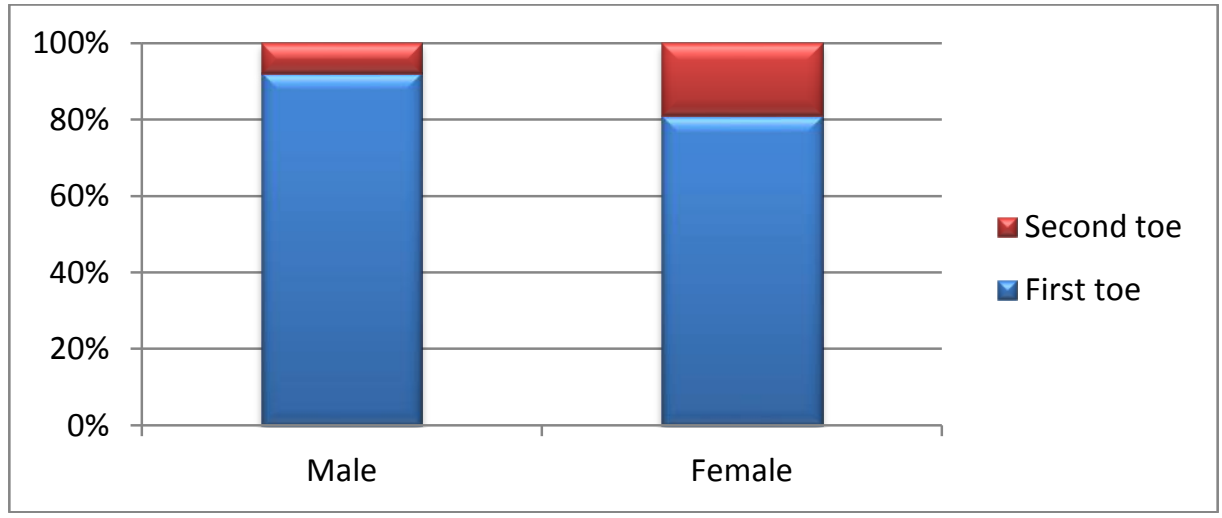

Figure (9): Frequency distribution of toe number used in foot length measurement. 


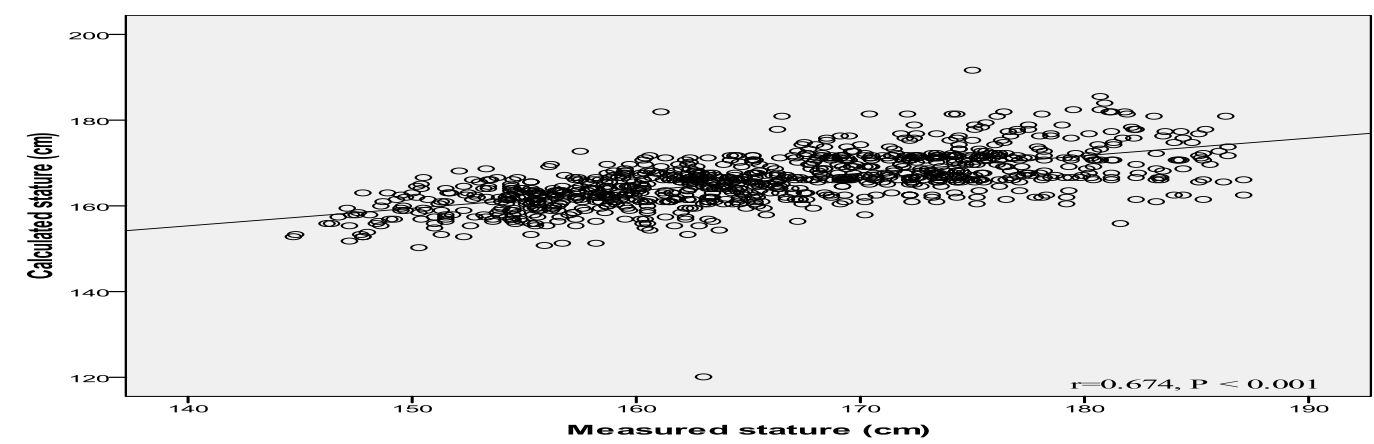

Figure (10): Scatter plot between measured stature and calculated stature according to hand length.

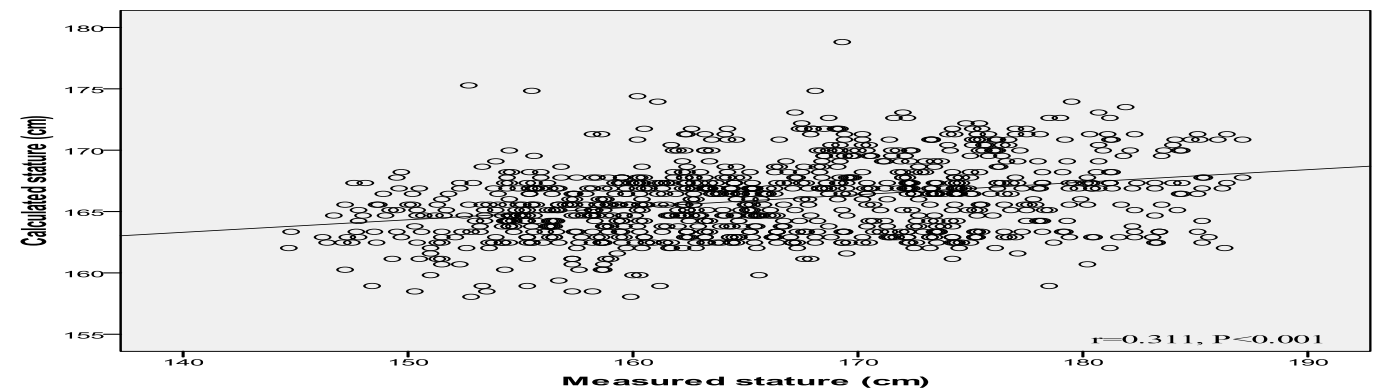

Figure (11): Scatter plot between measured stature and calculated stature according to hand width.

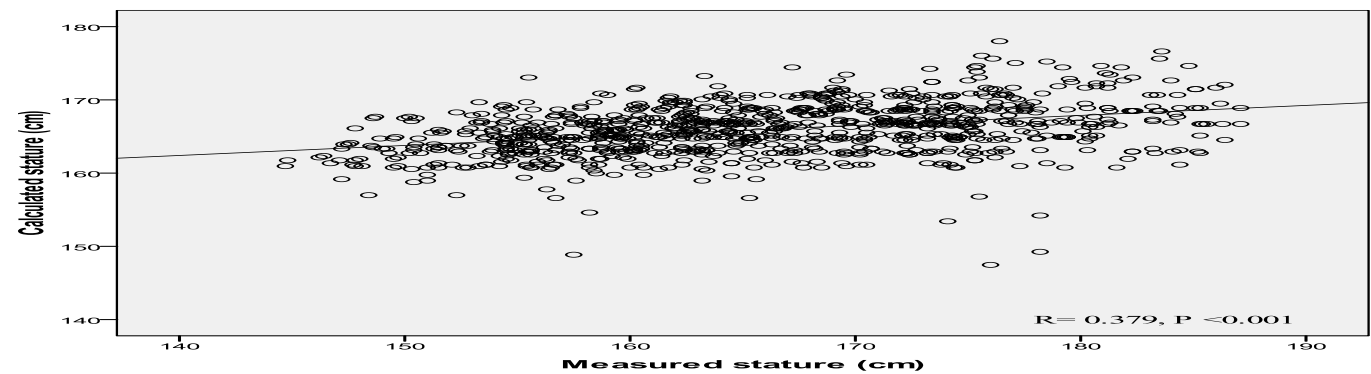

Figure (12): Scatter plot between measured stature and calculated stature according to foot length.

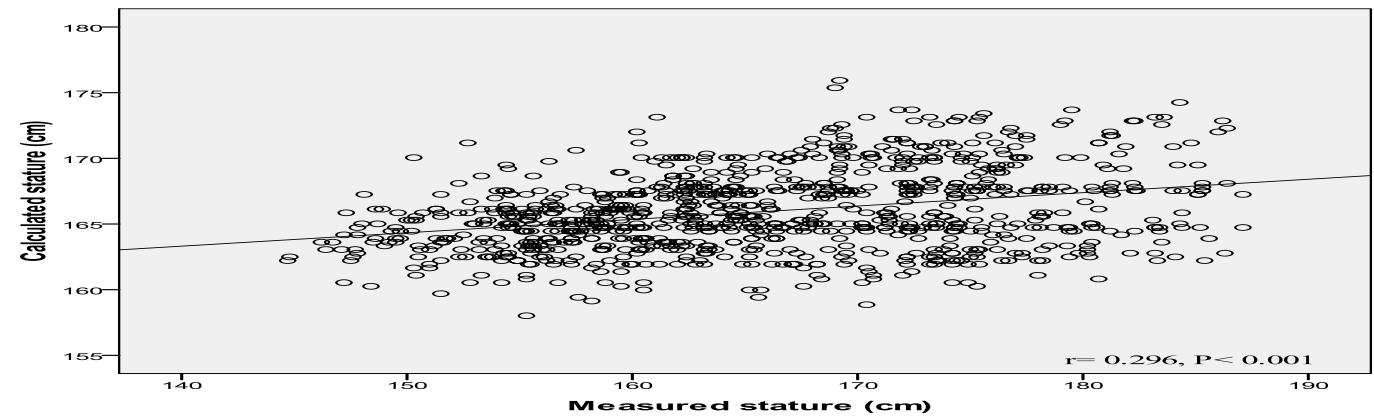

Figure (13): Scatter plot between measured stature and calculated stature according to foot width. 


\section{DISCUSSION}

Individual assessments as regard heath, socioeconomic factors can be conducted through anthropometric measurements throughout the life cycle. The World Health Organization provided anthropometric indexes and reference data at different ages for the assessment of health, nutrition, and social wellbeing (WHO, 1986).

Adult human stature, an important anthropometric parameter, is determined by several factors such as polygenic inheritance that define the physiological potential. On the other hand, environmental conditions such as nutrition, climate, and oxygen will determine to what extent this potential is realized (Canda, 2009; and Krishan et al., 2011).

In cases of mass disasters, identification of the victims from isolated extremities plays an important role. Furthermore, hand and foot dimensions have been used for identification of sex, age and stature in forensic investigations (Smith, 2007; and Kanchan et al., 2012). In forensic anthropology, estimation of the stature from the dimensions of the feet has a significant role in establishing personal identity (Kanchan et al., 2008; and Sen \& Ghosh, 2008).

Tang et al., 2012 studied the relationship between stature on one side and the dimensions of the hand and feet on the other side for forensic applications. A statistically significant correlation was found between the two variables in both sexes. However, the correlation coefficient was higher for hand length.

The present study revealed that the values of the stature were significantly higher in males than females. This was in concordance with the study conducted by AbdiOzaslan et al., 2012 which revealed that the mean value of stature for males $(n=224)$ is 1724.37 in $\mathrm{mm}$ while the mean value of stature for females $(n=132)$ is 1620.10 in $\mathrm{mm}$. Furthermore, the study carried by Sonali Khanapurkar et al., 2012 carried a study on one thousand adult healthy persons of both sexes and revealed similar results to the present study.

In this study, the linear regression analysis demonstrated a significant correlation between the stature and hand measurements. This was in concordance with AbdiOzaslan et al., 2012 who revealed similar results and described the linear regression analysis in millimeter for both males and females. As for males the stature equals $922.01+4.15$ and 1520.76 +2.45 for hand length and width respectively. The equation for females was stature $=1116.56+2.80$ hand length, and stature $=1298.32+$ 4.25 hand width.

Regarding the linear regression analysis in this study between the stature and foot measurements i.e. both foot length and width. Sonali \& Ashish, 2012 stated similar results and a correlation was recorded 
(height $=55.5+4.5$ foot length, and height $=59.7+5.7$ hand length). Furthermore, AbdiOzaslan et al., 2012 revealed similar results regarding the linear regression analysis between the stature and dimensions of the foot (stature $=840.88+3.52$ foot length, and stature $=1450.19+2.93$ foot width) for males and (stature $=941.95+2.96$ foot length, and stature $=1461.86+$ 1.84 foot width) for females.

In addition, Havna \& Nath, 2009 carried a study which revealed that the linear regression equations to estimate the stature from the foot dimensions among males was stature $=119.74+1.92$ foot length, and stature $=132.61+3.46$ foot width. While the linear regression equations among females was stature $=104.25$ +2.22 foot length, and stature $=132.33+2.49$ foot width. Furthermore, another study carried by Mansur et al., 2012 was conducted among students Nepal and revealed significant correlation between height and foot length ( $\mathrm{p}<0.01)$. The regression equation was stated height $=3.179$ foot length +87.65 .

The multivariate linear regression equation of stature in this study is as follow Stature $=100.220+9.578 \mathrm{x}$ (gender) +2.422 (hand length) $0.098 \times$ (age) +0.509 (foot length) + 1.123 (hand width) -0.539 (foot width). Gender is coded as 1 for males and 0 for females while all other variables are in $\mathrm{cm}$. So the equation for males is written as follows: stature $=100.220+9.578 \mathrm{x}$
(1) +2.422 (hand length) $-0.098 \mathrm{x}$ (age) +0.509 (foot length) +1.123 (hand width) -0.539 (foot width). While the equation for females is written as follows: stature $=100.220$ $+9.578 \times(0)+2.422$ (hand length) $0.098 \times$ (age) +0.509 (foot length) + 1.123 (hand width) -0.539 (foot width). AbdiOzaslan et al., 2012 showed that the multiple linear regression formulas for stature $(\mathrm{mm})$ from hand and foot dimensions as follows for males: stature $=746.16+2.31$ (hand length)

2.13(hand width) +2.85 (foot length) -0.08 (foot width). While it was: stature $=509.44+1.52$ (hand length) +2.59(hand width) +2.98 (foot length) -0.04 (foot width) for females.

\section{RECOMMENDATIONS}

Although a definite correlation between the stature and the foot length has been established in this study, further studies should be conducted in different regions due to the great variations between individuals due to ethnicity. Furthermore, the effect of the weight has to be studied.

\section{REFERENCES}

AbdiOzaslan, BeytullahKaradayi, Melek O. Kolusayin, Ahsen Kaya, HüseyinAfsin (2012): Predictive role of hand \& foot dimensions in stature estimation, Rom .J. Leg.; 20, 41-46.

Albert, A. M. (2012): Forensic Anthropology. Quoted from 
http://people.uncw.edu/albertm/w hat.htm

Havna B., Nath S. (2009) : Use of lower limb measurements in reconstructing stature among Shia Muslims, Int. J. of Biological Anthropolgy,vol.2 NO.2.

Beaton G., Kelly A., Kevany, J., Martorell R., Mason J. (1990): Appropriate Uses of Anthropometric Indices in Children - Nutritionpolicy discussion paper No. 7. A Report based on an ACC/SCN Workshop. Administrative committee on Coordination/subcommittee on Nutrition Acc/scn state - of - the-art series.

Bolstad G., Benum B., Rokne, A. (2001): Anthropometry of Norwegian light industry and office workers. Appl. Ergon. 32(3), 239-246.

Canda A. (2009): Stature Estimation from Body Segment Lengths in Young Adults-Application to People with Physical Disabilities-. J Physiol Anthropol. 28: 71-82.

Chikhalkar B.G., Mangaonkar A.A., Nanandkar S.D., Peddawad R.G., (2011): Estimation of Stature from Measurements of Long Bones, Hand and Foot Dimensions, J Indian Acad Forensic Med, 32(4).

De Onis M. and Habicht J.P. (1996):
Anthropometric reference data for international use: recommendations from a World Health Organization Expert Committee 1"3. Am J Clin Nutr. 64: 650-8.

DiMaggio J.A. and Vernon W. (2011): Forensic PodiatryPrinciples and Methods. Springer, New York, Dordrecht Heidelberg, London: Humana Press.

Fogel R.W. (1994): Economic Growth, Population Theory and Physiology: The Bearing of Long Term Processes on the Making of Economic Policy. Am Economic Rev. 84: 369-395.

Ilayperuma I., Nanayakkara G., Palahepitiya N. (2009): Prediction of Personal Stature based on the Hand Length. Galle Medical Journal.Vol 14: No. 1, September.

Kanchan T., KewalKrishan , Abhilasha Sharma (2012): Multiplication factor versus regression analysis in stature estimation from hand \&foot dimensions, J. For. Leg. Med. 19, 211-214.

Kanchan T., Menezes R.G., Moudgil R., Kaur R., Kotian M.S., Garg R.K. (2008): Stature Estimation from Foot Dimensions. Forensic Sci Int. 179(2-3):241.e1-5.

Krishan K. (2008): Estimation of stature from footprint and foot outline dimensions in Gujjars of North India. Forensic Sci Int. Mar 5; 175(2-3):93-101. 
Krishan K., Kanchan T., Passi, N. (2011): Estimation of Stature from the Foot and its Segments in a Sub-adult Female Population of North India.J Foot Ankle Res. 2011; 4: 24.

Lacia E., Leema, Tesfaye F. (2002): The Uses of Arm Span Measurement to Assess the Multinational Status of Adults in Four Ethiopian Ethnic Groups. Euro J ClinNutr. 56.

Lin Y., Wang M.J., Wang E.M. (2004): The comparisons of anthropometric characteristics among four peoples in East Asia. Applied Ergonomics. (35): 173178.

Mansur D.I., Haque M.K., Sharma K., Karki R.K., Khanal K ., Karna R (2012): Estimation of Stature from Foot Length in Adult Nepalese Population and its Clinical Relevance :Kathmandu Univ. Med. J., 37(1):16-19.

Mohanty B .B. , Agrawal D., Mishra K., Samantsinghar P., Chinara P. K. (2012): Estimation of height of an individual from foot length :Astudy on the population of Odisha,Int.J .Rev. Life .sci. 2 (2): 69-74.

Ozaslan A., Iscan M.Y., Ozaslan, I., Tugcu H., Koc S. (2003): Estimation of Stature from Body Parts. Forensic Sci Int. 132:4045.

Ozden, H.; Balci, Y.; Demirüstü, C.; Turgut, A. and Ertugrul, M. (2005): Stature and Sex
Estimate using Foot and Shoe Dimensions. Forensic Sci Int. 147:181-184.

Pheasant S. (1996): Body space: Anthropometry, Ergonomics and Design of Work. Taylor \&Francis, New York. pp. 15-45, 174-193.

Sen J. and Ghosh S. (2008): Estimation of Stature from Foot Length and Foot Breadth among the RAJBANSHI: an Indigenous Population of North Bengal. Forensic Sci Int. 25; 181(13):55.e1-6.

Smith S.L. (2007): Stature Estimation of 3-10-year-old Children from Long Bone Lengths. J Forensic Sci.52:538546.

Sonali Khanapurkar , Ashish Radke (2012) :"Estimation of stature from the measurement of foot length, hand length and head length in Maharashtra region, Indian Journal of Basic \& Applied Medical Research; Issue2, Vol. 1, 77-85.

Tang J, Chen R, Lai X. (2012): Stature estimation from hand dimensions in a Han population of Southern China, J Forensic Sci.,57(6):1541-4.

Waghmare V.K.R., Gaikwad, R.B., Herekar N. (2011): Estimation Of The Stature From The Anthropometric Measurement Of Hand Length. The Internet Journal of Biological Anthropology. Volume 4 Number 2. 
WHO Working Group (1986): Use and Interpretation of Anthropometric Indicators of Nutritional Status. Bull World Health Organ. 64:929-4

World Health Organization (WHO) (1995): Field Guide on
Rapid Nutritional Assessment in Emergencies. Alexandria. Egypt: World Health Organization Regional Office for the Eastern Mediterranean. 


\section{الملخص العربي - المي}

تحديد القامه من قياسات اليد والقدم فى السكان المصريين فى القاهرة الكبري

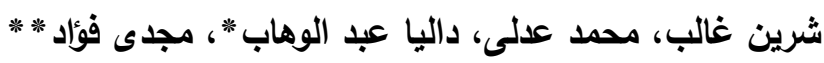

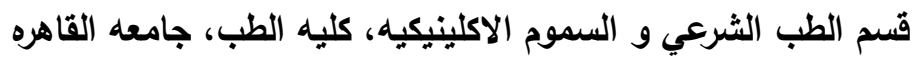

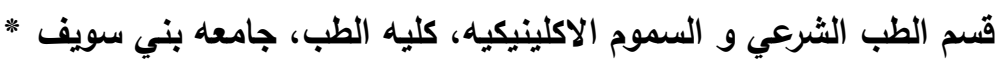

قسم الطب التشريح ، كليه الطب، جامعه القاهره "*

علم القياسات البشرية هو دراسة القياسات المقارنة لجسم الإنسان و ينوافر عدد من الألات الدقيقة للاراسات

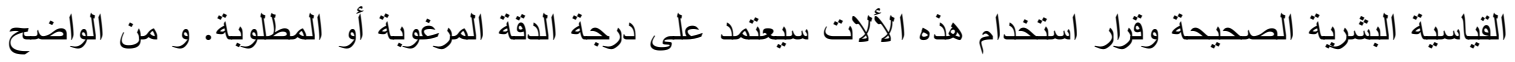

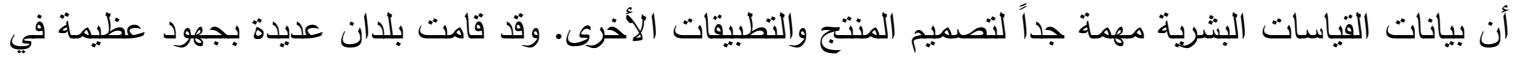
تأسيس قاعدة بيانات للقياسات البشرية للفئات السكانية المختلفة مثل المدنيين والأثخاص العسكريين والطلبة والعمال.

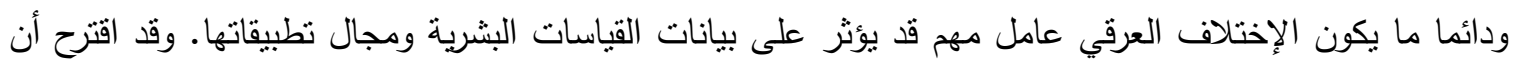

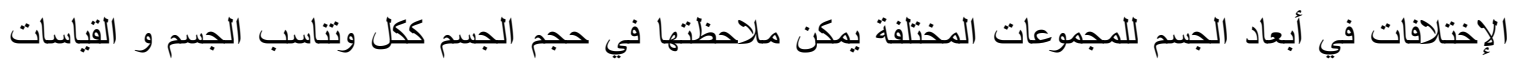
البثرية الرئيسية ، مثل القامة والإرتفاع جالسا ، هي أكثر الفروق النقليدية شيوعا بين الدجموعات العرقية.

القامة أو الإرتفاع واقفاً يعرف بأنه الدسافة بين قمة الرأس وسطح الوقوف وقياسه بعتمد على طول الأجزاء الدختلفة: الرأس والعمود الفقري والحوض والأطراف السفلية. وهو أحد أهم المؤثرات على حجم الجسم. وقامة الإنسان

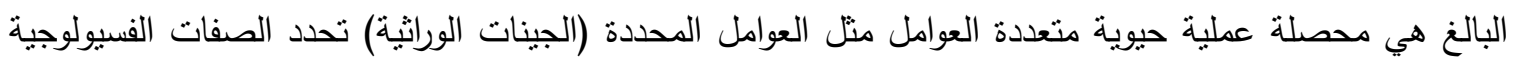

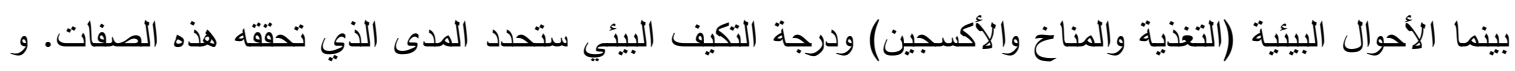

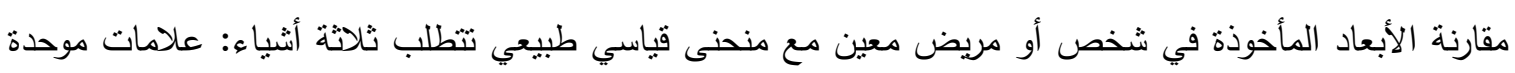

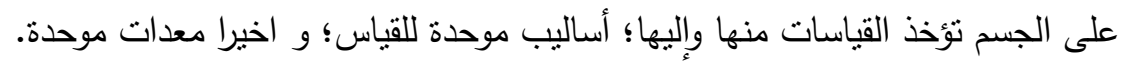

الهدف من الدراسة الحالية هو إقامة علاقة بين قامة الثخص وبين عرض وطول اليد والقدم له / لها فى الثى

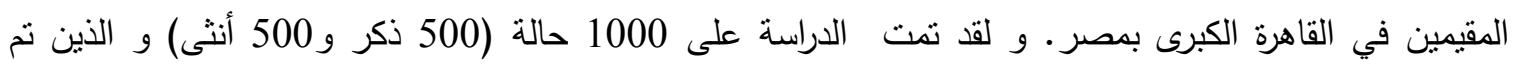
فحصهم، وتم قياس الآتي: قامة الثخص؛ طول اليد؛ عرض اليد؛ طول القدم؛ وعرض القدم. اما العوامل الأخرى فقد تضمنت العمر ونوع الحالة. و اقتصر عمر الحالات على الفترة بين 18- 60 عاما من العمر فى الدراسه الحاليه.

وقد تم تحليل الاختلافات في قامة الثخص؛طول اليد؛عرض اليد؛السن ؛طول القحموعرض القدم بين

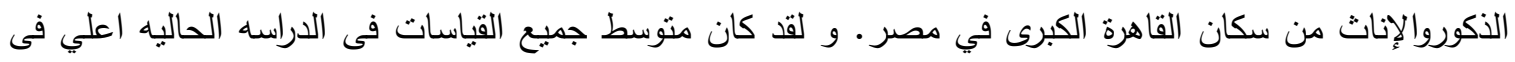
الذكورمنها في الاناث. و قد نم استخدام الانحدار الخطي الأوحد والمتعدد لتقدير القامة من ابعاد اليد والقدم لكلا الجنسين. و قد كانت معادلات الانحدار الخطي الاوحد كالتالى:

$$
\text { القامة = } 67.977 \text { +5.11 (طول اليد) القامة = } 126.244 \text { + } 4.417 \text { (العرض اليدان }
$$




$$
\text { القامة = } 114.748 \text { + } 1.983 \text { (طول القدم) القامة = } 136.184 \text { + } 2.799 \text { (عرض قدم) }
$$
ولوحظ وجود علاقة إيجابية ذات دلالة إحصائية بين القامة المحسوبة والقامة الفعلية التي كتبها تحليل الارتباط

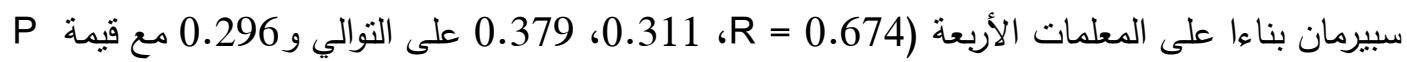
(ل0.001 > للجميع)

و لتقييم العوامل المؤثزة على القامة ، أجري تحليل متعدد المتغيرات متدرج الانحدار الخطي فيما يتعلق بالسن والجنس و طول اليد ، عرض اليد ، وطول القدم ، و عرض القدم. و قد كانت معادلة الانحدار الخطي متعدد

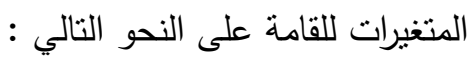
القامة = 100.220 + 9.578 ( الجنس) + 2.422 ( طول اليد ) - 0.098 (العمر بالسنين ) + 0.509

$$
\text { (طول القدم) + } 1.123 \text { (عرض اليد) - } 0.539 \text { ( عرض قدم ) }
$$

حيث يتم ترميز الجنسين ك( 1) للاككور و للإناث( 0 ) في حين أن جميع المتغيرات الأخرى بالسنتيميتز • وبالتالي فإن المعادلة للذكور مكتوبة على النحو التالي :

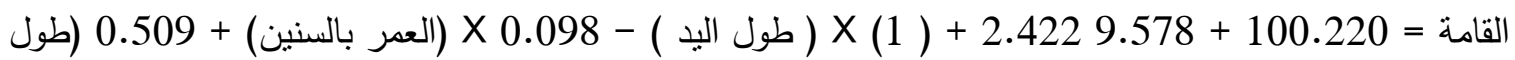
القدم) + 1.123 (عرض اليد) - 0.539 ( عرض القدم ). و المعادلة للإناث مكتوبة على النحو التالي :

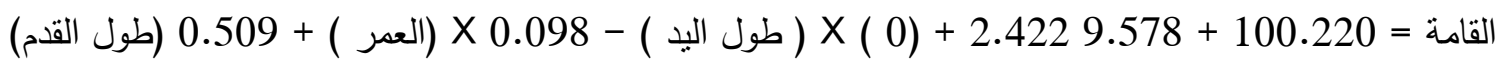

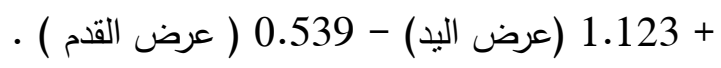

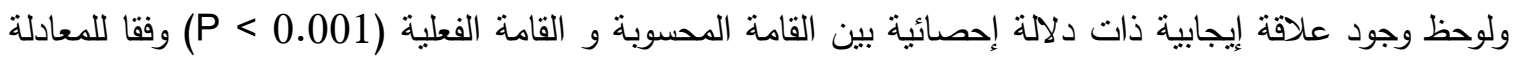
أعلاه ، فإنه يمكن ملاحظة أن الزيادة للقامة، في المتوسط ،هى حوالى دولى 9.578 سنتيميترللذكور فى حالة ان المتغيرات الأخرى ثابتة. 